\title{
DRUG-SENSITIVE ECTO-ATPASE IN HUMAN LEUKOCYTES
}

\author{
Fedor Medzihradsky, ${ }^{*}$ Edward I. Cullen, Hsia-lien lin and Giles G. Bole \\ Departments of Biological Chemistry, Pharmacology, and Internal Medicine, The University of \\ Michigan Medical Center, Ann Arbor, MI 48109, U.S.A.
}

(Received 11 October 1979; accepted 21 February 1980)

\begin{abstract}
An ecto-ATPase has been described in human leukocytes. The enzyme is present in both granulocytes and lymphocytes, exhibiting higher activity and substrate affinity in the latter cells, $K_{m}$ values ranged from $0.06 \mathrm{mM}$ in lymphocytes to $0.3 \mathrm{mM}$ in the unresolved leukocyte fraction. Enzymatic activity had a $\mathrm{pH}$ optimum in the physiological range, required $\mathrm{Mg}^{2+}$, and was insensitive toward ouabain and $\mathrm{Ca}^{2+}$. Potent inhibitors of ecto-ATPase were tricyclic antidepressants and substituted phenothiazines, to which the enzyme in lymphocytes was most susceptible. These drugs also decreased the phagocytic ability of leukocytes. However, while drug inhibition of the enzyme was reversible by washing, the effect on phagocytosis was not.
\end{abstract}

We have described previously an ecto-ATPase in rat leukocytes and reported the potent inhibition of the enzymatic activity by tricyclic antidepressants and substituted phenothiazines $[1,2]$. These drugs also markedly inhibited phagocytosis [3]. The inhibitory effects were not reproduced by a variety of drugs of different structures, investigated at identical concentrations. In human platelets, inhibition of ectoATPase has been linked to the loss of aggregating ability [4]. Our preliminary work provided evidence for the existence of ecto-ATPase in human leukocytes [5]. In view of the unknown function of this enzyme, and considering its potent inhibition by a number of drugs of wide clinical use, it was of interest to investigate further the properties of the ectoATPase in human leukocytes, including granulocytes and lymphocytes, and to characterize its interaction with drugs.

\section{MATERIALS AND METHODS}

Materials. The drugs used in this study were provided by Dr. H. H. Swain, Department of Pharmacology, The University of Michigan. The biochemicals and enzymes were purchased from the Sigma Chemical Co., St. Louis, MO, and from the Boehringer Mannhein Co., Indianapolis, IN. Plasmagel and Isolymph, solutions utilized for cell isolation, were purchased from the HTI Corp., Buffalo, NY and from Gallard-Schlesinger, Carle Place, NY, respectively.

Isolation of cells. Blood was obtained by venipuncture from healthy male and female volunteers not taking medications. Leukocytes were isolated according to a previously described procedure yielding cells of high purity and long term viability in vitro [6]. Granulocytes and lymphocytes wcre obtained by a recently developed method for the

*Author to whom correspondence should be addressed. concurrent isolation of these cells from the same sample of blood, focusing again on high purity and viability, particularly concerning plasma membrane integrity [7].

Buffer media and handling of cells. Many of the experimental steps were described previously in our study of this enzymatic activity in rat leukocytes $[1,2]$. Freshly isolated leukocytes, granulocytes or lymphocytes were suspended in a medium with the following composition $(\mathrm{mM}): \mathrm{Na}^{+}, 155.7 ; \mathrm{K}^{+}, 4.9$; $\mathrm{Mg}^{2+}, 1.2 ; \mathrm{Cl}^{-}, 131.3 ; \mathrm{SO}_{4}{ }^{2}, 1.2 ; \mathrm{HPO}_{4}{ }^{2-}, 13.3$; and $\mathrm{H}_{2} \mathrm{PO}_{4}^{-2}, 2.7$. These concentrations include the amounts of $\mathrm{Cl}^{-}$and $\mathrm{Na}^{+}$needed for $\mathrm{pH}$ adjustment. The medium was prepared as follows: $0.77 \mathrm{M} \mathrm{NaCl}$, $200 \mathrm{ml} ; 0.77 \mathrm{M} \mathrm{KCl}, 8 \mathrm{ml} ; 0.77 \mathrm{MMgSO}_{4}, 2 \mathrm{ml} ; 0.5 \mathrm{M}$ $\mathrm{Na}_{2} \mathrm{HPO}_{4}$ buffer, adjusted to $\mathrm{pH} 7.4$ with $\mathrm{HCl}, 40 \mathrm{ml}$; and $\mathrm{H}_{2} \mathrm{O}, 1000 \mathrm{ml}$. Glucose, in amounts to give $10 \mathrm{mM}$ final concentration, was added in solid form to aliquots of the above medium. The final $\mathrm{pH}$ of the medium was adjusted to 7.4 with $\mathrm{NaOH}$. In general, the freshly isolated cells were incubated for $60 \mathrm{~min}$ at $37^{\circ}$ prior to starting the particular experiment. After the cell count was determined, the suspension was centrifuged at $80 \mathrm{~g}$ for $7 \mathrm{~min}$ and the pellet was resuspended at $37^{\circ}$ to the required cell concentration with a buffer medium of the following composition (mM): Tris, $35 ; \mathrm{NaCl}, 120 ; \mathrm{KCl}, 5$; $\mathrm{MgCl}_{2}, 2.5$; and glucose, 10 . The $\mathrm{pH}$ of the medium was adjusted to 7.4 with $\mathrm{HCl}$.

Enzyme kinetics and inhibition. For the determination of kinetic constants $\left(K_{\mathrm{m}}, V_{\max }\right), 50 \mu \mathrm{l}$ of cell suspension in the Tris-based medium and $50 \mu \mathrm{l}$ of the medium containing ATP at twice the final concentration desired were pipetted into $1.5 \mathrm{ml}$ polyethylene tubes (Eppendorf Microanalytical System). Mixing of these solutions represented the beginning of the enzyme assay. The latter was terminated at $30 \mathrm{~min}$ by the addition of $400 \mu \mathrm{l}$ of ice-cold $0.6 \mathrm{M}$ $\mathrm{HClO}_{4}$. The tubes were centrifuged for $10 \mathrm{~min}$ at $1900 \mathrm{~g}$ in the cold, and inorganic phosphate $\left(\mathrm{P}_{i}\right)$ was determined in the supernatant fraction by a procedure described previously [1]. 
Briefly, aliquots of $250 \mu \mathrm{l}$ were placed in $4 \mathrm{ml}$ tubes, and $250 \mu \mathrm{l}$ of a color reagent was added. The composition of the latter was $144 \mathrm{mM} \mathrm{FeSO}_{4}$ in $8.15 \mathrm{mM}$ ammonium molybdate $/ 580 \mathrm{mM} \mathrm{H} \mathrm{H}_{2} \mathrm{SO}_{4}$. The absorbance of the samples at $700 \mathrm{~nm}$ was determined within the linear range of the standard curve, established by using potassium phosphate. Blanks, containing either ATP and no biological material or of the opposite composition, were included in each assay. Some of the drugs used in this study interfered in the colorimetric determination of $\mathrm{P}_{\mathrm{i}}$. In such cases, $\mathrm{P}_{\mathrm{i}}$ was quantitated by an enzymatic method using phosphorylase $a$, phosphoglucomutase and glucose6-phosphate dehydrogenase to measure fluorometrically the formation of reduced nicotinamide adenine dinucleotide phosphate [8]. If $\mathrm{P}_{\mathrm{i}}$ was determined by the latter method [1], the ATPase reaction was terminated by placing the tubes in a boiling water bath for $8 \mathrm{~min}$, followed by centrifugation at $1900 \mathrm{~g}$ for $10 \mathrm{~min}$. Aliquots of the supernatant fluid were added to $1 \mathrm{ml}$ of the prepared reagent containing all the necessary components except for phosphorylase. After mixing and taking the initial reading of fluorescence, the reaction was started by the addition of the latter enzyme. The rate of enzymatic reaction was monitored on a recorder. After its completion, the second reading of all the samples was taken. Appropriate standards of $\mathrm{P}_{i}$ were included in each set of analyses.

In experiments on enzyme inhibition, the methodology outlined above was followed in general with the following exceptions. To $40-\mu \mathrm{l}$ aliquots of the cell suspension was added $10 \mu \mathrm{l}$ of a solution of the drugs in the buffer medium at concentrations five times that utilized during the assay. The suspension was subsequently incubated for $15 \mathrm{~min}$ at $37^{\circ}$, at which time $50 \mu \mathrm{l}$ of double-strength ATP solution was added and the assay mixture further incubated for $30 \mathrm{~min}$. The subsequent steps were as outlined above.

Determination of phagocytic index. Quantitation of phagocytosis was carried out as described [9]. Briefly, $100 \mu \mathrm{l}$ each of leukocyte suspension, fresh human serum, buffer medium and heat-killed Staphylococcus aureus in phosphate-buffered saline (to give a 10 -fold excess of bacterial particles over the number of cells) were mixed at $0^{\circ}$ using siliconized glassware. Cover slip preparations of the above mixture were incubated at $37^{\circ}$ for $30 \mathrm{~min}$ in a moist chamber, and then dried and treated with Wright's stain. By microscopic examination at $2080 \times$ magnification, the total number of particles ingested by 100 consecutively counted phagocytic cells was averaged and expressed as the phagocytic index.

Determination of protein. The method of Lowry et al. [10] was applied.

\section{RESULTS}

Characterization of ecto-ATPase activity in leukocytes. Linearity of the enzyme assay with time and protein concentration was established initially (Fig. 1). Unaltered permeability of the cells during the experiment was ascertained by measuring the cell content of $\mathrm{K}^{+}$(Table 1), a sensitive criterion of membrane integrity [11]. The $\mathrm{pH}$ optimum of
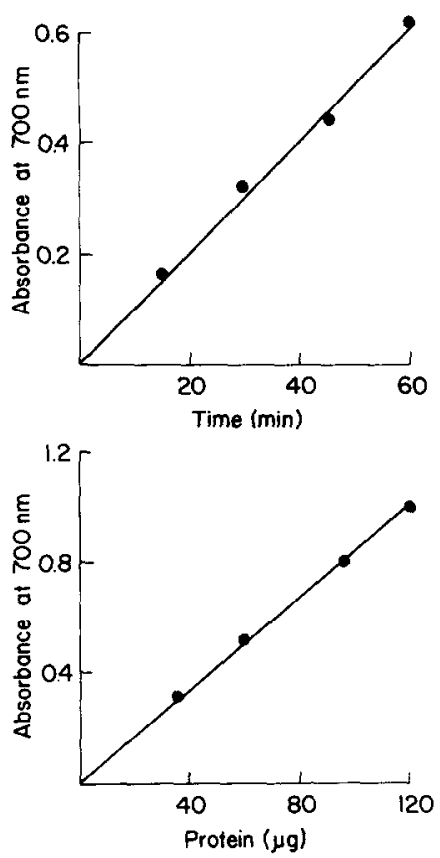

Fig. 1. Linearity of ecto-ATPase assay with time and protein. Approximately $1 \times 10^{6}$ leukocytes were incubated in the presence of $3 \mathrm{mM}$ ATP for various lengths of time at $37^{\circ}$ (upper graph). In other experiments, various concentrations of cells corresponding to the amount of protein as indicated were incubated for $30 \mathrm{~min}$ at $37^{\circ}$. The further steps, including the assay of enzymatic activity, were carried out as described under Materials and Methods. Presented are the results of a representative experiment.

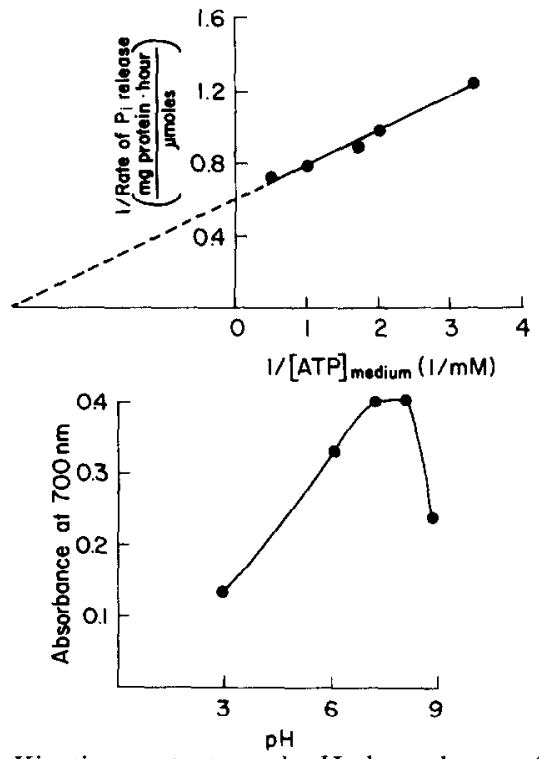

Fig. 2. Kinetic constants and pH dependence of ectoATPase in leukocytes. Data for Lineweaver-Burk plots of ATPase activity (upper graph) were obtained by incubating cells in the presence of various concentrations of ATP for $30 \mathrm{~min}$ at $37^{\circ}$. Liberated $P_{i}$ and protein were determined as described under Materials and Methods. Enzymatic activity as a function of $\mathrm{pH}$ (lower graph) was determined in the presence of $3 \mathrm{mM}$ ATP. Prior to the assay, the $\mathrm{pH}$ of the phosphate-based buffer medium described under Materials and Methods was adjusted to the values indicated. Unaltered cell viability under such conditions was ascertained by the determination of cellular $\mathrm{K}^{+}$. Presented are results of representative experiments. 
Table 1. Plasma membrane permeability of leukocytes incubated under various conditions*

\begin{tabular}{cc}
\hline $\begin{array}{c}\text { Conditions of } \\
\text { incubation }\end{array}$ & $\begin{array}{c}\text { Ratio } \\
\text { (cell K } / \text { cell Na}\end{array}$ \\
\hline In ATPase assay medium: \\
$10 \mathrm{~min}, 37^{\circ}$ \\
$30 \mathrm{~min}, 37^{\circ}$ & $3.9 \pm 0.2$ \\
$45 \mathrm{~min}, 37^{\circ}$ & $4.1 \pm 0.2$ \\
$60 \mathrm{~min}, 37^{\circ}$ & $3.9 \pm 0.2$ \\
In ATPase assay medium, $45 \mathrm{~min}, 37^{\circ}$, with: & $3.8 \pm 0.3$ \\
Desipramine $(0.5 \mathrm{mM})$ & \\
Amitriptyline $(0.5 \mathrm{mM})$ & $4.1 \pm 0.4$ \\
Mesoridazine $(0.5 \mathrm{mM})$ & $4.3 \pm 0.2$ \\
Promazine $(0.5 \mathrm{mM})$ & $4.0 \pm 0.1$ \\
Trifluoperazine $(0.5 \mathrm{mM})$ & $3.5 \pm 0.2$ \\
Thioridazine $(0.2 \mathrm{mM})$ & 0.1 \\
Thioridazine $(0.5 \mathrm{mM})$ & 0.2 \\
\hline
\end{tabular}

\footnotetext{
* Mean values and standard deviations of three to four experiments are
} shown.

enzyme activity included the physiological range, and extended above $\mathrm{pH} 8$ before sharply declining (Fig. 2). The insensitivity of the enzyme towards ouabain and metabolic inhibitors, and the strong inhibitory effect of EDTA (Table 2) were properties similar to those observed in rat leukocytes [2]. The specific dependence of the enzyme on $\mathrm{Mg}^{2+}$ was demonstrated, and an interference by glucose phosphate phosphatases was excluded. ATPase activity did not increase as a result of various procedures used to disrupt the plasma membrane (Table 2). The $K_{m}$ and $V_{\max }$ of ATPase in intact leukocytes was $0.32 \mathrm{mM}$ and $1.83 \mu \mathrm{moles} / \mathrm{mg}$ protein $/ \mathrm{hr}$ respectively (Fig. 2).
While tricyclic antidepressants and substituted phenothiazines potently inhibited the ecto-ATPase (Table 3), drugs of different structure had no effect on the enzyme. It was ascertained that ATPase inhibition can be obtained under conditions of unaltered plasma membrane permeability, as shown by the unchanged ratio of cellular $\mathrm{K}^{+} / \mathrm{Na}^{+}$during the assay in the presence of the particular inhibiting drugs (Table 1). On the other hand, several halogencontaining drugs that potently inhibited ecto-ATPase also induced a marked loss of cellular $\mathrm{K}^{+}$.

Inhibition of ecto-ATPase and the suppression of phagocytosis by drugs in human leukocytes exhibited a positive correlation (Table 3). Both phenomena

Table 2. Effects of various agents and of cell-disrupting procedures on ecto-ATPase*

\begin{tabular}{lc}
\hline \multicolumn{1}{c}{$\begin{array}{c}\text { Agent (final concn. in mM) } \\
\text { or treatment of cells }\end{array}$} & $\begin{array}{c}\text { ATPase activity } \\
\text { (\% of control) }\end{array}$ \\
\hline EDTA (5) & 21 \\
$N$-Ethylmaleimide (1) & 64 \\
2,4-Dinitrophenol (3) & 71 \\
Sodium arsenite (5) & 78 \\
Iodoacetamide (1) & 80 \\
Ca $^{2+}(6)$ & 81 \\
Oligomycin (57 $\mu$ g/ml) & 87 \\
p-Chloromercuribenzoic acid & 89 \\
Ouabain (0.5) & 104 \\
Hypotonicity & 44 \\
French press & 50 \\
Hypertonicity $\ddagger$ & 59 \\
Freeze-thaw\$ & 70 \\
Freeze-thaw and homogenization 1 (hand) & 77 \\
Mechanical homogenization (3000 rpm) & 104 \\
Mechanical homogenization (hand) & 95 \\
\hline
\end{tabular}

* Shown are mean values of four experiments except for hypo- and hypertonicity, which were tested in two experiments, all run in triplicates. The standard deviation around the mean was in all cases less then 10 per cent.

+ Cells were suspended in deionized water for $30 \mathrm{sec}$ at $37^{\circ}$.

\$ Leukocytes were exposed to a 5 -fold hypertonic Tris buffer medium for $30 \mathrm{sec}$ at $37^{\circ}$.

$\$$ Cells were rapidly frozen at $-70^{\circ}$ and thawed to room temperature. The cycle was carried out three times.

If An all-glass Potter-Elvehjem homogenizer was used. 


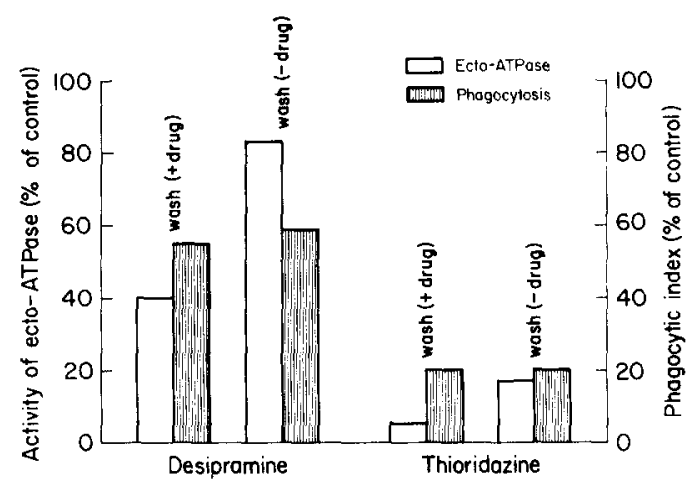

Fig. 3. Reversibility of ecto-ATPase inhibition by drugs. Suspensions of leukocytes were incubated with and without $0.5 \mathrm{mM}$ desipramine or $0.15 \mathrm{mM}$ thioridazine for $15 \mathrm{~min}$ at $37^{\circ}$. Subsequently, the cell suspension was centrifuged at $3000 \mathrm{~g}$ for $5 \mathrm{~min}$ and the supernatant fluid was decanted. The pellet was resuspended with either buffer medium containing the drug at a concentration identical to that used in the incubation, or with buffer alone. After repeating the washing procedure, aliquots of the suspension were subjected to assay to ATPase activity and of phagocytosis as described under Materials and Methods. Presented are mean values of four experiments utilizing different preparations of the cells. In all experiments the standard deviation around the mean was less than \pm 5 per cent.

were assessed with cells from the same preparation of leukocytes. Enzyme inhibition by both tricyclic antidepressants and substituted phenothiazines was reversible (Fig. 3). Although the degree of inhibition by desipramine and thioridazine was markedly different, the per cent recovery of enzymatic activity after washing was comparable. On the other hand, phagocytosis, inhibited by either desipramine or thioridazine, did not exhibit a trend toward recovery after washing of the cells (Fig. 3).

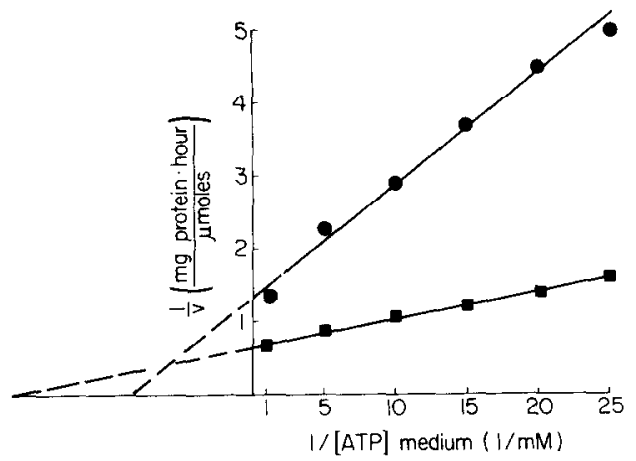

Fig. 4. Kinetic constants of ecto-ATPase in granulocytes and lymphocytes. Approximately $1 \times 10^{6}$ cells were incubated with various concentrations of ATP as indicated. Further steps were as described in the legend to Fig. 2. The data were plotted according to Lineweaver-Burk. Presented are the mean values of three experiments.

Characteristics of ecto-ATPase in granulocytes and lymphocytes. It should be emphasized that these two populations of leukocytes were isolated concurrently from the same sample of blood. The kinetic constants of ecto-ATPase in granulncytes and lymphocytes were: $K_{m}, 0.12 \mathrm{mM}$ and $0.06 \mathrm{mM}, V_{\max }, 0.7$ and 1.56 $\mu$ moles/mg protein/hr (Fig. 4). The pattern of enzyme inhibition obtained with desipramine and promazine, representative of tricyclic antidepressants and substituted phenothiazines, was similar in both cell types (Fig. 5). However, the enzyme in lymphocytes was more sensitive to drug inhibition. As observed with the unresolved fraction of leukocytes, phenothiazines were more potent inhibitors of ecto-ATPase. Among the latter compounds, promazine was selected for this study because it inhibited the enzyme without affecting plasma mem brane permeability (Table 1).

Table 3. Effects of drugs on ecto-ATPase and on phagocytosis in leukocytes*

\begin{tabular}{lccc}
\hline & \multicolumn{1}{c}{ ATPase activity (\% of control) } & $\begin{array}{c}\text { Phagocytic index } \\
\text { (\% of control) }\end{array}$ \\
\cline { 2 - 4 } Drugs & $0.2 \mathrm{mM}$ Drug & $0.5 \mathrm{mM} \mathrm{Drug}$ & $0.5 \mathrm{mM} \mathrm{Drug}$ \\
\hline Imipramine & 88 & $60 \pm 4$ & $73 \pm 10$ \\
Desipramine & 76 & $49 \pm 3$ & $63 \pm 8$ \\
Amitriptyline & 70 & $47 \pm 6$ & $47 \pm 8$ \\
Nortriptyline & 64 & $45 \pm 3$ & $40 \pm 5$ \\
Protriptyline & 64 & $43 \pm 6$ & $42 \pm 5$ \\
Mesoridazine & 104 & $81 \pm 8$ & $54 \pm 8$ \\
Promazine & 78 & $48 \pm 2$ & $62 \pm 4$ \\
Chlorpromazine & 43 & $32 \pm 5$ & $9 \pm 2$ \\
Perphenazine & 30 & $26 \pm 3$ & $9 \pm 2$ \\
Trifluoperazine & 31 & $18 \pm 3$ & $9 \pm 1$ \\
Thioridazine & 40 & $14 \pm 1$ & $96 \pm 10$ \\
Amphetamine & & $99 \pm 4$ & $89 \pm 6$ \\
Morphine & $98 \pm 3$ & $172 \pm 9$ \\
Phenobarbital & & $95 \pm 3$ & \\
Phenelzine & & $100 \pm 3$ & \\
\hline
\end{tabular}

* Mean values and standard deviations of three to four experiments are showit. 


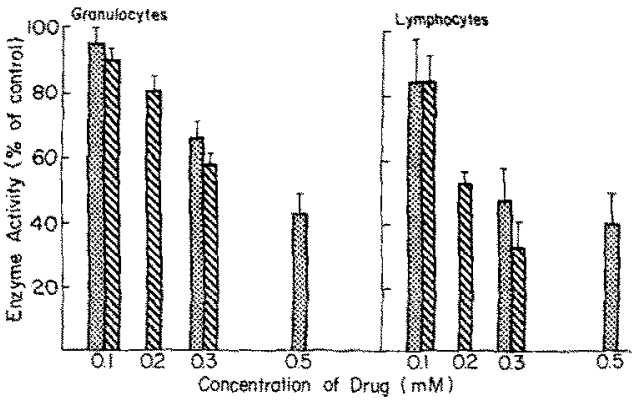

Fig. 5. Inhibition by drugs of ecto-ATPase in granulocytes and lymphocytes. Aliquots of cell suspensions corresponding to approximately $3 \times 10^{5}$ cells were incubated with the indicated concentrations of desipramine (it) or promazine (N) for $15 \mathrm{~min}$ at $37^{\circ}$. After the addition of $1.0 \mathrm{mM}$ and $0.6 \mathrm{mM}$ ATP to granulocytes and lymphocytes, respectively, the suspensions were further incubated for $30 \mathrm{~min}$ and then placed in ice. Subsequent treatment of the cells and the determination of $P_{i}$ were as described under Materials and Methods. Shown are the mean values and standard deviations of three experiments.

\section{DISCUSSION}

Ecto-ATPase activity was present in both granulocytes and lymphocytes. Its localization was established by ascertaining plasma membrane integrity during the course of the enzyme assay. The latter property was assessed by the cellular levels of $\mathrm{K}^{+}$, a sensitive criterion of plasma membrane perturbation $[11,12]$. Furthermore, disruption of the cells by various methods did not lead to an increase of ATPase activity. Ecto-ATPase had been described previously in human platelets [4] and, in a preliminary communication, we reported its presence in human leukocytes [5]. Subsequently, an ectoATPase in human granulocytes was reported [13]. In the present study, the characteristics of ectoATPase in human leukocytes were investigated, followed by a comparison of its properties in granulocytes and lymphocytes. The characteristics of the enzyme in human leukocytes were similar to those described for such enzymes in other cells (e.g. in Refs. 14-16), with the exception of a neuroblastoma cell line in which ecto-ATPase was stimulated by $\mathrm{Ca}^{2+}[17]$. The human leukocyte ecto-ATPase was dependent on $\mathrm{Mg}^{2+}$, had a $\mathrm{pH}$ optimum in the physiological range, and its $K_{m}$ was $0.3 \mathrm{mM}$. Although information on ATP concentration in human plasma is equivocal, ranging from low $\mu \mathrm{M}$ levels to completely absent [15], in human blood the level of this compound reaches $1 \mathrm{mM}$ [18].

The effect on the enzyme of various inhibitors, including ouabain and metabolic poisons, was similar to that observed in rat leukocytes [2] and in human granulocytes [13]. The most potent inhibition was obtained by $N$-ethylamaleimide, whereas $\mathrm{Ca}^{2+}$ moderately decreased the enzyme activity. A specific feature of ecto-ATPase in rat leukocytes was its inhibition by drugs [1]. The corresponding human enzyme also exhibited this property, displaying a positive correlation between enzyme inhibition and suppression of phagocytosis. This phenomenon was not observed in human granulocytes, in which inhi- bition of ecto-ATPase by suramin did not impair phagocytic ability [13]. Our investigation of the link between leukocyte ecto-ATPase and phagocytosis was based on the assumed involvement of the enzyme in cell-specific surface phenomena, in analogy to the observed correlation in human platelets between inhibition of ecto-ATPase and cell aggregation [4]. The observed inhibition by drugs of ecto-ATPase and of phagocytosis in leukocytes of the rat [3] and human (Table 3 ) led us to investigate the activity of the enzyme and its properties in both granulocytes and lymphocytes from human blood. The two types of leukocytes were separated from the same sample blood by a recently developed procedure yielding cell fraction of high purity [7]. Considering the virtual lack of cross-contamination, the possibility that the ecto-ATPase observed in this study in lymphocytes was due to contamination by granulocytes can be excluded. Furthermore, compared to the latter cells, the enzymatic activity in lymphocytes exhibited both high activity and affinity for its substrate and an increased sensitivity towards inhibitors. Although no previous information is available on ecto-ATPase in human leukocytes per se, the reported kinetic constants of the enzyme in granulocytes [13] agree well with those determined in this work. In general, $K_{m n}$ values for ecto-ATPase from various sources range between 0.03 and $0.3 \mathrm{mM}$ (e.g. Refs. 2, 15 and 17). On the other hand, a much greater difference exists in the reported data for $V_{\text {max }}$.

The inhibition by drugs occurred without changes in membrane permeability, as indicated by the unaltered cell content of $\mathrm{K}^{+}$after exposure to drugs. However, several of the halogenated substituted phenothiazines, in addition to inhibiting the enzyme, greatly increased the permeability of the plasma membrane, suggesting further-going drug-membrane interaction. In contrast to the partial reversal of enzyme inhibition by washing of the cells, this step had no effect on phagocytosis. Such dissociation of the two phenomena represents suggestive evidence for differences in the mechanisms by which drug inhibition of ecto-ATPase and of phagocytosis occurs. Although the effects of the tricyclic drugs on platelet ecto-ATPase have not been investigated, the inhibition of platelet aggregation by imipramine and chlorpromazine has been reported [19]. The inhibitory concentrations of the drugs (Table 3 ) were considerably higher then their therapeutic range, e.g. plasma levels of combined desipramine and imipramine ranged between 107 and $698 \mathrm{ng} / \mathrm{ml}$, the latter value corresponding to approximately $2.5 \mu \mathrm{M}[20]$. However, non-specific protein binding of these drugs is substantial and thus their accumulation in tissues is likely [21].

Considering the ecto nature of leukocyte ATPase, any hypothesis on the functional role of this enzyme has to postulate the availability of extracellular ATP. While uncertainties exist about the concentration of ATP in plasma, its compartmentation within the plasma membrane, as suggested for platelets, cannot be ruled out [22]. Extracellular synthesis of ATP by various normal and malignant cell lines [23] and transfer of cytoplasmic ATP to the extracellular environment have been reported [24]. An additional aspect requiring clarification is the biological conse- 
quence of the hydrolysis of extracellular ATP by ecto-ATPase. Possible functional roles of such a process have been discussed, including the regulation of negative charges on cell surfaces [25] and an involvement in the blood clotting mechanism by providing extracellular ADP [15]. Included in such considerations is a possible function of ecto-ATPase in granulocytes of hydrolyzing ATP derived from tissue damage, within the scavenger role of these cells. The involvement of ecto-ATPase in leukocyte aggregation, in analogy to such a relationship shown in platelets, has not been investigated. Although human granulocytes but not lymphocytes responded to chemotactic factors [26], recently such a response was reported also for rat lymphocytes [27]. According to a recent report, extracellular ATP, at concentrations of $0.5 \mathrm{mM}$, increased passive plasma membrane permeability [28], particularly of transformed cells [29]. It is of interest that this concentration of ATP correlates well with the observed $K_{m}$ values for leukocyte ecto- $\Lambda$ TPases. By its involvement in the control of extracellular ATP, an ectoATPase could assume a role in regulating cell membrane permeability.

Acknowledgements--This work was supported in part by USPHS Grants 5 RO1 EY02450 and AM20557, and by a stipend of the University of Michigan Cancer Research Institute (E.I.C.).

\section{REFERENCES}

1. F. Medzihradsky, M. J. Marks and H. Lin, Life Sci. 16, 1417 (1975).

2. F. Medzihradsky and H. Lin, Life Sci. 16, 1429 (1975).

3. F. Medzihradsky, G. G. Bole, L. M. Nork and H. Lin, Res. Commun. Chem. Path. Pharmac. 14, 277 (1976).

4. R. G. Manson and S. R. Saba, Am. J. Path. 55, 215 (1969).

5. G. G. Bole and F. Medzihradsky, Fedn. Proc. 36, 970 (1977).
6. F. Medzihradsky, M. J. Marks and J. I. Metcalfe, Biochem. Med. 10, 153 (1974).

7. E. I. Cullen and F. Medzihradsky, Biochem. Med., in press.

8. D. W. Schulz, J. V. Passonneau and O. H. Lowry, Analyt. Biochem. 19, 300 (1967).

9. G. G. Bole, Jr., G. W. Jourdian and J. E. Wright, $J$. Lab. clin. Med. 86, 1018 (1975).

10. O. H. Lowry, N. J. Rosebrough, A. L. Farr and R. J. Randall, J. biol. Chem. 193, 265 (1951).

11. F. Medzihradsky and M. J. Marks, Biochem. Med. 13, 164 (1975).

12. F. Medzihradsky and J. I. Metcalfe, J. Lab. clin. Med. 85, 342 (1975).

13. J. S. Smolen and G. Weissman. Biochim. biophys. Acta. 512, 525 (1978).

14. J. W. DePierre and M. L. Karnofsky. J. biol. Chem. 249, 7111 (1974).

15. J. W. DePierre and M. L. Karnofsky, J. biol. Chem. 249, 7121 (1974).

16. E. G. Trams and C. J. Lauter, Biochim. biophys. Acta 345, 180 (1974).

17. V. Stefanovic, M. Ledig and P. Mandel, J. Neurochem 27, 799 (1976).

18. E. Kolb, in Biochemisches Taschenbuch (Ed. H. M. Rauen), Vol. 2, p. 361. Springer, New York (1964).

19. D. C. B. Mills and G. C. K. Roberts, Nature, Lond. 213, 35 (1967).

20. L. E. Hollister, J. Am. med. Ass. 241, 2530 (1979).

21. O. Borga, D. L. Azarnoff, G. P. Forshell and F. Sjöquist, Biochem. Pharmac. 18, 2135 (1969).

22. G. V. R. Born, Nature, Lond. 194, 927 (1962).

23. G. Agren, J. Ponten, G. Ronquist and B. Westermark, J. cell. Physiol. 77, 331 (1971).

24. E. G. Trams, Nature, Lond. 252, 480 (1974).

25. B. M. Jones, Nature, Lond. 212, 362 (1966).

26. J. T. O'Flaherty, D. L. Kreutzer and P. A. Ward, $A m$. J. Path. 90, 537 (1978).

27. P. A. Ward, E. R. Unanue, S. Gorolnick and G. Schriner, J. Immun. 119, 416 (1977).

28. E. Rozengurt and L. A. Heppel, J. biol. Chem. 254, $708(1979)$.

29. N. R. Mavan, Expl. Cell Res. 114, 417 (1978). 